\title{
Unge og gjentatte selvmordsforsøk
}

\author{
Ved Berit Grøholt
}

\begin{abstract}
Tenåringer som trenger sykehusbehandling etter et selvmordsforsøk, kan ha en høy dødelighet de nærmeste årene, og mange gjentar selvmordsforsøket. Hva predikerer en slik atferd? Vi intervjuet ungdom som var lagt inn på somatisk sykehus etter et selvmordsforsøk i Oslo eller Akershus i tidsrommet 1992-94 (Groholt et al., 2000b), og gjentok undersøkelsen blant de samme ungdommene etter 8-10 år. I denne artikkelen vil vi redegjøre for studien som viste at det er ungdommenes beskrevne følelser, deres forhold til foreldre og alvorlighetsgrad av psykiske vansker som best predikerer at selvmordsfors $\emptyset \mathrm{k}$ gjentas. 1)
\end{abstract}

Selvmordsatferd i ungdomsårene skiller seg på noen områder fra selvmordsforsøk hos voksne, selv om mye er felles (H jelmeland \& Groholt, 2005). Selvmord er forholdsvis sjelden i denne aldersgruppen, men selvmordsforsøk er til gjengjeld svært hyppig. Det har derfor vært en tendens til at man oppfattet selvmordsforsøk i tenårene som mindre alvorlig enn i voksen alder, selv om vi har sparsom kunnskap om hvordan det går med de ungdommene som utfører et sel vmordsforsøk før fylte 20 år.

\section{Tidligere studier}

D e få oppfølgingsstudiene vi har etter selvmordsatferd blant unge er sjelden prospektive, og mange av dem tar utgangspunkt i gjennomsnittlige ungdomsgrupper som har rapportert selvmordsforsøk i spørreundersøkel ser (epidemiologiske studier). Studiene viste at de faktorene som karakteriserte unge som gjentok et sel vmordsforsøk, på mange måter var identiske med faktorer som øker risikoen for selvmordsatferd generelt: et tidligere selvmordsforsøk, depresjon, aggressiv eller utagerende atferd, skoleproblemer, familieproblemer, lav selvfølelse, håpløshet, impulsivitet, sosial isolasjon, dødsfall i familien og stor grad av samsykelighet (komorbiditet) (Brent et al., 1993; H ulten et al., 2001; Lewinsohn et al., 1994; Spirito et al., 2003). I tillegg har tidligere studier vist at høy grad av medisinsk alvor i selvmordsforsøkene ikke var typisk for de som gjentok selvmordsforsøk - i motsetning til et uttalt ønske om å dø, som predikerte senere selvmord (Kotila, 1989).

\section{Forskningsspørsmål}

I et forsøk på å forbedre kunnskapen om fremtidsutsiktene for unge som innlegges etter selvmordsforsøk, ble ungdommer som hadde vært innlagt på somatisk sykehus etter et selvmordsforsøk kontaktet igjen etter ca. 8-10 år. De hadde tidligere samtykket i å bli kontaktet for å være med i en etterundersøkelse. Spørsmålene etterundersøkelsen skulle besvare er:

1. H vor vanlig er gjentatte selvmordsforsøk og sel vmord blant tenåringer ca. 9 år etter et selvmordsforsøk?

2. H vor høy er dødeligheten blant ungdommene som har vært innlagt for et selvmordsforsøk?

3. Vil forhold som karakteriserer tenåringer som forsøker selvmord, predikere senere selvmordsatferd?

\section{Beskrivelse av de unge}

I en 18-månedersperiode i 1992-94 kom 106 unge mennesker i kontakt med et sykehus i O slo og A kershus etter selvmordsforsøk. 12 ble utskrevet umiddelbart og 2 ville ikke delta, slik at 92 ble intervjuet av artikkelforfatteren ( $\mathrm{G}$ roholt et al., 2000a). De hadde en gjennomsnittsalder på 16,9 år og $90 \%$ var jenter. Litt under halvparten av dem hadde gjort et alvorlig selvmordsforsøk, bedømt etter Beautrais kriterier (Beautrais, 2004). Disse ungdommene ga tillatelse til at de kunne kontaktes senere, og forskeren har truffet dem igjen 8-10 år senere.

I denne studien ønsket vi å ta utgangspunkt i forhold ved den første undersøkelsen som kunne forklare, eller som $ø k$ te risikoen for, at de unge senere gjentok et selvmordsforsøk eller døde.

\section{Undersøkelsesmetoder}

Intervjuene i 1992-94 hadde gitt kunnskap om al der, kjønn, yrke/skole, etnisitet, familieforhold (om man bodde med biologiske foreldre eller ikke) og sosioøkonomisk status. Vi fikk også informasjon om de unge selvmordsforsøkerne hadde hatt skoleproblemer, om de hadde vært atskilt fra foreldrene i noen periode mer enn to måneder, om de hadde opplevd seksuell eller psykisk mishandling, om de hadde blitt mobbet og om de hadde vært i kontakt med barnevernet. H vis de svarte ja på noen av disse spørsmål ene, beskrev de forholdene nærmere. Vi fikk også mål for konflikter mellom foreldrene og med foreldrene, og om noen av foreldrene misbrukte alkohol (dvs. at de var beruset atskillige ganger hver måned). De unge ble også spurt om hvem de søkte kontakt med i van skelige situasjoner (forelder, venner eller andre) (Buhrmester, 1990; M euus, 1989). Deres tilknytning til forel drene ble kartlagt med selvutfyllingsinstrumentet Parental Bonding Index (Parker et al., 1979). Dette instrumentet gir et mål for i hvilken grad foreldrene ble opplevd som omsorgsfulle, og i hvilken grad de var kontrollerende.

De unge anga også i hvilken grad de hadde god eller dårlig fysisk helse. Basert på et grundig klinisk intervju fikk vi oversikt over eventuelle psykiske lidelser da de ble innlagt for sitt selvmordsforsøk. A tskillige av de unge hadde flere diagnoser. De unge fylte ut en rekke anerkjente spørreskjemaer som beskrev ulike typer problematferd og ulike typer vanskelige følelser og opplevelser (Youth Self Report YSR) (A chenbach \& Edelbrock, 1993). A ndre spørreskjema kartla depressive følelser (Beck Depression Inventory, BDI) (Beck et al., 1988), følelse av håpløshet (Beck H opelessness Scale) (Beck et al., 1974), ensomhetsfølelse (U CLA Lineliness Scale) (Russell et al., 1978). Videre fikk vi vite om de hadde mottatt behandling for psykiske plager, og om de hadde gjort tidligere selvmordsforsøk før forskeren traff dem første gang. Bruk av alkohol og illegale rusmidler var også kartlagt.

1) Dette er et sammendrag av artikkelen G roholt $B$, Ekeberg $0, H$ aldorsen $T$. A dolescent suicide attempters: what predicts future suicidal acts? Suicide Life Threat Behav. 2006 Dec;36(6):638-50. Berit G røholt har foretatt alle intervjuene. 


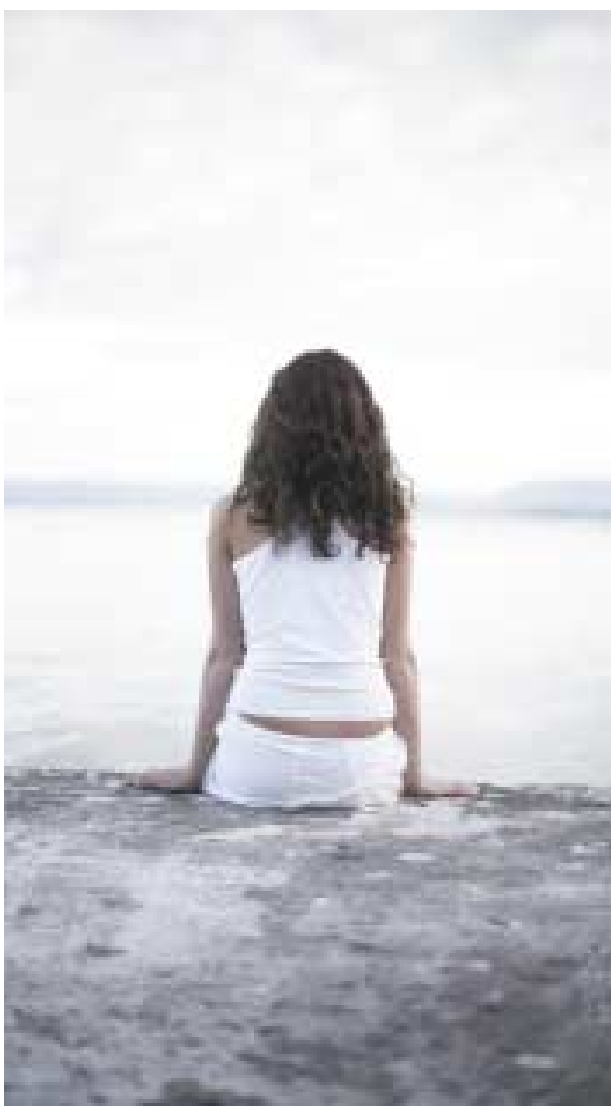

Selvmordsforsøk som førte til innleggelse var godt beskrevet, bl.a. hadde vi et mål for hva ungdommene egentlig ønsket å oppnå med selvmordsforsøket (Suicide Intent Scale). D enne skalaen inneholder to deler; den ene gir et uttrykk for hva de unge faktisk gjorde for eventuelt å dø, og den andre delen for hva de ønsket å oppnå med handlingen.

\section{RESULTATER}

\section{Selvmordsatferd}

Etter 8 år ble samtlige unge forsøkt kontaktet. A v de 92 var 5 døde. Det lyktes forskeren å oppnå kontakt med 73 (84 \%) av de unge, og av dem hadde 31 ( $42 \%$ ) foretatt ett eller flere nye selvmordsforsøk. De 14 som ikke var med i studien, rapporterte hyppigere enn de som var med konflikter mellom foreldrene sine, ellers var det ingen statistisk signifikante forskjeller mellom dem og de 78 deltagerne. $N$ oen av dem som senere var døde hadde også gjort et nytt selvmordsforsøk, slik at i alt 33 av de $78(73+5)$ hadde gjentatt et sel vmordsforsøk i oppfølgingsperioden.
Til sammen hadde de gjort 116 selvmordsforsøk. $\mathrm{N} \mathrm{i}$ av ungdommene hadde gjort fire eller flere forsøk. Ca. $75 \%$ av de 78 gjorde et nytt forsøk etter 20 -årsalderen . A ltså var dette ikke et uttrykk for tenåringsatferd, selv om ca. 2/3 av dem gjorde et nytt selvmordsforsøk i løpet av de første to årene etter første undersøkelse.

Fem av de unge var som nevnt døde, og disse dødsfallene var fordelt utover hele oppfølgingsperioden. Den standardiserte mortalitetsraten var 13,2 for hele gruppen. For guttene var den 10,9 og for jentene 13,9. Det betyr at jentene hadde 13,9 ganger større risiko for å dø sammenliknet med gjennomsnittsungdom av samme al der og kjønn.

\section{Hvilke forhold predikerer ny selvmordsatferd?}

I det følgende vil vi sammenlikne to grupper av ungdommene (de som hadde gjentatt selvmordsforsøk mot de som ikke hadde gjentatt) når det gjelder en rekke enkeltvariabler.

\section{Demografiske forhold}

$M$ ange av de forholdene som var undersøkt, var likt fordelt mellom de som gjentok et selvmordsforsøk og de som ikke gjorde det. Det gjaldt alder, om de gikk på skole eller ikke, om de hadde skilte eller gifte foreldre, etnisitet og sosioøkonomiske klasse. Vi laget også en egen gruppe av de 5 som døde. Denne gruppen skilte seg ikke ut fra gruppen for øvrig på noen av disse forholdene.

\section{Livshendelser}

Svært mange av de unge hadde opplevd store problemer i barndomsperioden, som atskillelser, skilsmisse, overgrep og alkoholmisbruk i familien. De søkte forholdsvis sjelden støtte hos foreldre når verden gikk dem imot. H eller ikke disse forholdene skilte mellom de som gjentok selvmordsforsøk og ikke. De som gjentok selvmordsforsøket, oppfattet både mødre og fedre som mindre omsorgsfulle enn de som ikke gjentok selvmordsforsøket. $N$ år vi så på sammenhengen mellom lav omsorg og svært kontrollerende atferd, beskrev de som gjentok selvmordsforsøk oftere foreldrene som lite omsorgsfulle og samtidig kontrollerende.
Problematiske følelser og atferd

Instrumentet YSR gir tre ulike hovedskårer: en skåre for alle typer problemer, en skåre for internaliserende problemer (dvs. problemer knyttet til angst, depresjon og utrygghet) og for eksternali serende problemer (dvs. problemer knyttet til utagerende atferd). De som gjentok selvmordsforsøk hadde en høyere problembelastningskåre, og de hadde også høyere skåre på de internal iserende problemene. 0 gså andre spørreskjema skilte gruppene fra hverandre. De som hadde forsøkt selvmord, hadde høyere skåre på målet for depresjon (BDI) og håpløshet, og de hadde lavere sel vfølelse. Impulsivitet, ensomhet eller utagerende atferd skilte ikke de to gruppene fra hverandre.

\section{Diagnoser}

Få av diagnosene skilte mellom de som gjentok og de som ikke gjentok selvmordsforsøket. Bare diagnosen personlighetsforstyrrelse var vanligere blant de som gjentok forsøk ( $33 \%$ vs. $13 \%$ ). Av de som gjentok forsøk, hadde $61 \%$ en depressiv lidelse i motsetning til $42 \%$ av de som ikke gjentok, men denne forskjellen var ikke statistisk signifikant. De som gj entok forsøket, hadde oftere mottatt behandling for psykiske vansker før de gjorde det første selvmordsforsøket, og de hadde også flere ganger skadet seg selv før det første selvmordsforsøket.

\section{Selvmordsforsøket}

$\mathrm{N}$ år vi så på selve selvmordsforsøket, hadde 75 av de 78 brukt forgiftning med medikamenter. M en verken metoden som var brukt, alvorlighetsgrad, intensjon, om det skjedde impulsivt, om de skrev et avskjedsbrev eller om de sa de ønsket å dø, skilte gruppene fra hverandre. Det var heller ikke mulig å skille de som døde, fra de som ikke døde. To av de som døde, døde av selvmord mens tre døde av andre årsaker.

\section{Alle forhold sett i sammenheng}

$\mathrm{N}$ år man analyserer slike risikofaktorer, er det vanlig å se om risikofaktorene overlapper hverandre. I dette tilfellet var det 12 forhold som skilte de to gruppene fra hverandre. A lle disse 12 forholdene (lav omsorg fra mor, lav omsorg fra far, streng far med lav omsorg, personlighetsforstyr- 
relse, stor samsykelighet, tidligere selvmordsforsøk, høy skår på total problemer og på internaliseren de problemer på YSR, høy depresjonsskåre, lav selvfølel se og høy grad av håpløshet) ble inkludert i en felles analyse (multivariat logistisk regresjon). Følelsene av håpløshet, depressive følelser og lav selvfølelse (målt gjennom tre ulike spørreskjema) var knyttet til hverandre (viste positiv signifikant korrelasjon), og når analysen var fullført, viste det seg at det var 4 faktorer som hadde en effekt: $\mathrm{H} ø y$ grad av rapportert følelse av håpløshet, antall diagnoser, om de hadde mottatt psykiatrisk behandling, og at de beskrev faren som kontrollerende uten omsorg. U avhengig av hverandre økte disse forholdene risikoen for et selvmordsforsøk, det vil si at de hadde prediktiv verdi.

\section{Diskusjon}

\section{Selvmordsforsøk har alvorlig prognose}

D enne studien viser at tenåringer som trenger sykeh usbehandling etter et selvmordsforsøk, kan ha en høy dødelighet de nærmeste 10 år, og at mange gjentar selvmordsforsøket. Dette skjer også etter tenårene. Konklusjonen er at problemene som fører til et selvmordsforsøk, ikke er rene ungdomsproblemer som unge vokser seg ut av.

Følgene av en slik kunnskap er at alle tenåringer som innlegges etter et selvmordsforsøk må utredes grundig, og en må være villig til å bruke ressurser for å få dette til. $\mathrm{H}$ adde samme dødelighet og samme tilbakefall sprosent vært beskrevet for en somatisk lidelse ( som f. eks. kreft), ville ingen anstrengel ser for å gi god behandling være for store.

D e subjektive følelsene de unge besk rev at de slet med var viktige, selv om følelsene ikke lett ble observert av andre.

Videre viser studien at mange av de unge som innlegges etter selvmordsforsøk, har store sosiale problemer å bale med. De ytre forholdene er for mange (men ikke for alle) problematiske, og spiller selvsagt stor rolle for hvordan de unge opplever hverdagen. M en de færreste av disse problemene fører i seg selv til gjentatt selvmordsatferd. Det er verd å merke seg at

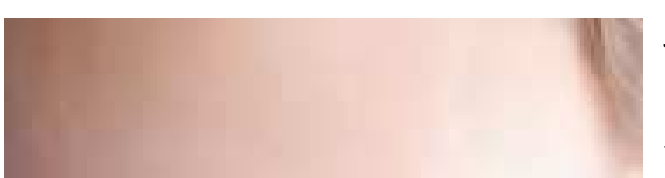

Alvorlighetsgrad av problemer er viktig Studien viser også at bare diagnosen personlighetsforstyrrelse predikerer gjentatt selvmordsforsøk. Depresjon har ingen klar selvstendig effekt på gjentagelser. $\mathrm{H}$ eller ikke alvorlige psykiske lidelser som schizofreni og bipolar lidelse gjør utslag.

Dette funnet trenger flere kommentarer. $\mathrm{N}$ år vi stiller diagnosen depresjon, bruker vi et grensemål: $\mathrm{H}$ vis summen av plager ligger over grensen, setter vi diagnosen depresjon. Er summen under grensen, selv om bare ett symptom mangler, blir ingen diagnose satt. M ye taler for at det er nyttigere å se på depresjon på en skala (som en dimensjon), der plager like under grenseverdien kan ha alvorlige følger. Dette er i tråd med flere internasjonale studier (Fergusson et al., 2005), og understrekes av at depresjonsmål fra spørreskjema (BDI) har prediktiv verdi for gjentatt selvmordsforsøk i denne studien. Videre viser vår studie at antall et diagnoser øker risikoen for gjentakelse. M ange samtidige diagnoser betyr i praksis

det er følelsene de unge selv beskriver som har størst prediktiv verdi. D et har etter min mening flere praktiske konsekvenser.

1. M an skal lytte til de unges opplevelse av sin egen situasjon med det største alvor. En fare er at vi hjelpere legger større vekt på vår egen opplevelse av de ytre problemene, og bruker "objektive" mål for å bedømme en situasjon. Budskapet er at de unges subjektive opplevelse er langt viktigere enn hjelperes evt. tolkning av situasjonen.

2. O fte sies det at de unge skader seg som et rop om hjelp. Funn både fra denne studien og fra andre forskningsstudier (Boergers et al., 1998) viser at en slik tolkning ikke samsvarer med det de unge opplever. Dette understrekes i denne etterundersøkelsen; det som er vondest for de unge, er deres egne følelser som de sjelden tror de kan få hjelp for. I gjen er konklusjonen at vi må lytte til den unge, selv om den unge i formen kan virke umoden og ikke greier å uttrykke seg slik at det blir logisk for en voksen hjelper. sammen satte problemer, og kan sees som et indirekte mål for alvorlighetsgrad av psykisk lidelse. A ha mottatt behandling for psykisk lidelse tidligere kan også sees som er mål for alvorlighetsgrad. En annen tolkning kan være at behandling i seg selv er skadelig. De unges opplevelse av den behandlingen de hadde fătt, tydet imidlertid ikke på at det kan være en rimelig tolkning.

$\mathrm{H}$ ovedkonklusjonen blir derfor at det er viktigere for osså se på alvorligh etsgrad av psykiske plager en n enkeltdiagnoser. Det kan synes overraskende at alvorlige lidel sene som schizofreni og bipolar lidelse ikke ble funnet ved den innledende undersøkelsen. $\mathrm{Vi}$ vet at disse lidelsene ofte debuterer i tenårene. I flere tilfeller var det rimelig grunn til å tro at den unges plager representerte tidlige tegn på en av disse lidelsene, men symptomene var slik at summen kom under grensesnittet og at det derfor ikke var formelt riktig å sette en slik diagnose. I ettertid utviklet også flere av de unge slike sykdommer, men det inngår ikke som funn i denne studien. En som hadde en klar 
bipolar lidelse ved første undersøkelse, døde ved selvmord før etterundersøkelsen. Budskapet fra disse funnene er at vi bør søke å stille diagnosen schizofreni og bipolar lidelse tidlig der det er grunn til det, og føl ge opp sakene selv om en på grunnlag av symptomene ikke kan stille en sikker diagnose.

\section{Funn fra tidligere studier}

Det kan også synes overraskende at forhold ved selvmordsforsøket ikke varslet om risiko for gjentatt selvmordsforsøk. Funnet er i tråd med flere tidligere studier (Kienhorst et al., 1995). Klinisk vil de fleste legge vekt på alvoret i et selvmordsforsøk, og etter min mening bør en slik vurdering inngå i klinikerens risikovurdering. I denne studien var de fleste selvmordsforsøkene forholdsvis impulsive og lite alvorlige medisinsk sett: U t fra funn i vår studie er det derfor vanskelig å mene noe om effekten av selvmord med høy grad av planlegging og systematisk atferd.

Funnene i denne studien samsvarer godt med funn i andre studier som er nevnt tidligere. N oen andre studier har funnet at ytre forhold, som overgrep, har en prediktiv effekt (Beautrais, 2004). Disse studiene har kortere oppføl gingstid og omfatter ikke perioden mellom tenåringsalder og ung voksen alder. I denne perioden skjer store forandringer i de fleste menneskers liv, og det kan være en av grunnene til at det ytre ikke skiller mellom gruppene. $U$ an sett om slike forhold påvirker faren for gjentatt selvmordsatferd eller ikke, vil det ytre være viktig for den unges liv og bør vektlegges i et behandlingsopplegg.

\section{Studiens svakheter}

I likhet med de fleste andre studier har denne studien svakheter som gjør at en bør ta funnene med forbehold. Siden studien omfatter 78 personer, kan den ha for svak statistisk styrke til å avdekke sammenhenger. Rapporter om sel vmordsatferd i oppfølgingsperioden kan være upresise, siden ikke alle tilfellene var dokumentert med rapporter fra sykehus eller behandlere. M ye har hendt i løpet av oppfølgingstiden som kan være av avgjørende betydning for utfallet, uten at det er tatt med i studien. Imidlertid er funnene ment å være nyttige for en som står overfor en suicidal tenåring, og framtidens hendelser vil i en slik klinisk situasjon være ukjente. En annen svakhet er den skjeve kjønnsfordelingen, det er vanskeligå si noe om kjønnsforskjeller.

\section{Konklusjon:}

Lytt nøye til unge som har forsøkt selvmord. D et er deres beskrevne følelser, forhold til foreldre og alvorlighetsgrad av psykiske vansker som best predikerer at selvmordsforsøk gjentas.

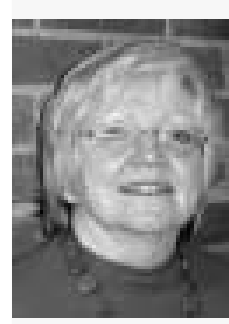

B erit G røholt er barnepsykiater og professor dr. med. ved U niversitetet i 0 slo. H un har lang klinisk erfaring fra arbeid med barn og ungdom. H ennes doktorgradsarbeid omhandlet selvmord og selvmordsforsøk blant barn og unge.

\section{Referanser}

A chenbach, T. M . \& Edelbrock, C. S. (1993). $M$ anual for the Youth Self report and Profile. Bulington, VT: Department of Psychiatry, U niversity of Vermont.

Beautrais, A . L. (2004). Further suicidal behavior among medically serious suicide attempters. Suicide and Life Threatening Behavior, 34, 1-11.

Beck, A . T., Steer, R. A ., \& G arbin, M. G . (1988) Pschycometric properties of the beck depression inventory: twenty-five years of evaluation.

Clinical Psychological Review, 8, 77-100.

Beck, A . T., W eissman, A ., Lester, D., \& Trexler L. (1974). The measurement of pessimism: the hopelessness scale. Journal of $C$ onsulting and Clinical Psychology, 42, 861-865.

Boergers, J., Spirito, A ., \& Donaldson, D. (1998). $R$ easons for adolescent suicide attempts: associations with psychological functioning. Journal of the A merican A cademy of $\mathrm{C}$ hild and $\mathrm{A}$ dolescent Psychiatry, 37, 1287-1293.

Brent, D. A., Kolko, D. ., Wartella, M. E., Boylan, M. B., M oritz, G ., Baugher, M . et al. (1993). A dolescent psychiatric inpatients' risk of suicide attempt at 6- month follow-up. Journal of the A merican A cademy of $C$ hild and $A$ dol escent Psychiatry, 32, 95-105.

Buhrmester, D. (1990). Intimacy of friendship, interpersonal competence, and adjustment during preadolescence and adolescence. Child

Development, 61, 1101-1111.
Fergusson, D. M., H orwood, L. J., Ridder, E. M ., $\&$ Beautrais, A . L. (2005). Subthreshold depression in adolescence and mental health outcomes in adulthood. A rchives of $\mathrm{G}$ eneral Psychiatry, 62 66-72.

G roholt, B., Ekeberg, O ., \& H aldorsen, T. (2006) A dolescent suicide attempters: what predicts future suicidal acts? Suicide and Life T hreatening Behavior, 36, 638-650.

Groholt, B., Ekeberg, 0.\& Haldorsen, T. (2000a). A dolescents hospitalised with deliberate selfharm: the significance of an intention to die. European Child \& A dolescent Psychiatry, 9, 244254

G roholt, B., Ekeberg, O ., W ichstrom, L., \& $\mathrm{H}$ aldorsen, T. (2000b). Young suicide attempters: a comparison between a clinical and an epidemiological sample. Journal of the A merican A cademy of $C$ hild and $A$ dolescent Psychiatry, 39, 868-875.

H jelmeland, H.\& Groholt, B. (2005). A comparative study of young and adult deliberate selfharm patients. $C$ risis, 26, 64-72.

Hulten, A ., Jiang, G . X., W asserman, D., H awton, K., H jelmeland, H., De Leo, D. et al. (2001). R epetition of attempted suicide among teenagers in Europe: frequency, timing and risk factors. European Child \& A dolescent Psychiatry, 10, 161 169

Kienhorst, I. C., De W ilde, E. J., Diekstra, R. F., \& Wolters, W. H. (1995). A dolescents' image of their suicide attempt. Journal of the A merican A cademy of $\mathrm{C}$ hild and $\mathrm{A}$ dolescent Psychiatry, 34, 623-628.

Kotila, L. (1989). Suicide and violent death among adolescent suicide attempters. A cta Psychiatrica Scandinavia, 79, 453-459.

Lewinsohn, P. M ., Rohde, P., \& Seeley, J. R. (1994) Psychosocial risk factors for future adolescent suicide attempts. Journal of C onsulting and Clinical Psychology, 62, 297-305.

M euus, W. (1989). Parental and peer support in adolescence. In K. H urrelmann \& U. Engel (Eds.) The social world of adolescents. International perspectives (pp. 167-183). Berlin: Walter de G ruyter.

Parker, G ., Tupling, H ., \& Brown, L. B. (1979). A parental bonding instrument. British Journal of M edical Psychology, 52, 1-10.

Russell, D., Peplau, L. A ., \& Ferguson, M. L. (1978). D eveloping a measure of loneliness. Journal of Personality A ssessment, 42, 290-294.

Spirito, A ., Val eri, S., Boergers, J., \& Donaldson, D. (2003). Predictors of continued suicidal behavior in adolescents following a suicide attempt. Journal of $\mathrm{Clinical} C \mathrm{C}$ ild and $\mathrm{A}$ dolescent Psychology, 32, 284-289. 